\title{
Management and characteristics of recycled manure solids used for bedding in Midwest freestall dairy herds
}

\author{
A. W. Husfeldt, ${ }^{\star}$ M. I. Endres, ${ }^{\star 1}$ J. A. Salfer, $†$ and K. A. Jannił \\ *Department of Animal Science, University of Minnesota, St. Paul 55108 \\ †University of Minnesota Extension, St. Cloud 56303 \\ ‡Department of Bioproducts and Biosystems Engineering, University of Minnesota, St. Paul 55108
}

\begin{abstract}
Interest in using recycled manure solids (RMS) as a bedding material for dairy cows has grown in the US Midwest. Cost of common bedding materials has increased in recent years and availability has decreased. Information regarding the composition of RMS and its use as a bedding material for dairy cows in the Midwest is very limited. The objectives of this study were to characterize RMS as a bedding material, observe bedding management practices, document methods of obtaining RMS, and describe housing facilities. We visited 38 Midwest dairy operations bedding freestalls with RMS to collect data. Methods of obtaining RMS for bedding included separation of anaerobic digested manure, separation of raw manure, and separation of raw manure followed by mechanical drum-composting for 18 to $24 \mathrm{~h}$. Average bedding moisture of unused RMS was $72.4 \%$ with a $\mathrm{pH}$ of 9.16 . Unused samples contained (on a dry basis) $1.4 \% \mathrm{~N}, 44.9 \% \mathrm{C}, 32.7 \mathrm{C}: \mathrm{N}$ ratio, $0.44 \% \mathrm{P}, 0.70 \% \mathrm{~K}, 76.5 \%$ neutral detergent fiber, $9.4 \%$ ash, $4.4 \%$ nonfiber carbohydrates, and $1.1 \%$ fat. Moisture was lowest for drum-composted solids before and after use as freestall bedding. After use in the stalls, digested solids had lower neutral detergent fiber content $(70.5 \%)$ than drum-composted $(75.0 \%)$ and separated raw $(73.1 \%)$ solids. Total $\mathrm{N}$ content was greater in digested solids $(2.0 \%)$ than in separated raw $(1.7 \%)$ solids. Total bacterial populations in unused bedding were greatest in separated raw manure solids but were similar between digested and drum-composted manure solids. Drum-composted manure solids had no coliform bacteria before use as freestall bedding. After use as bedding, digested manure solids had lower total bacteria counts compared with drum-composted and separated raw manure solids, which had similar counts. Used bedding samples of digested solids contained fewer
\end{abstract}

Received October 28, 2011.

Accepted December 20, 2011.

${ }^{1}$ Corresponding author: miendres@umn.edu environmental streptococci than drum-composted and separated raw solids and had reduced Bacillus counts compared with separated raw solids. Coliform counts were similar for all 3 bedding sources. Addition of a mechanical blower post-separation and use of a shelter for storage were associated with reduced fresh-bedding moisture but not associated with bacterial counts. This was the first survey of herds using RMS for bedding in the Midwest. We learned that RMS was being used successfully as a source of bedding for dairy cows. For most farms in the study, somatic cell count was comparable to the average in the region and not excessively high. Key words: bedding characteristic, bacterial count, recycled manure solids

\section{INTRODUCTION}

Increased costs and reduced availability of common bedding materials such as straw and sawdust have prompted dairy producers to search for alternative bedding sources. Sand can be considered the ideal bedding source for dairy cows as it offers improved cow comfort especially due to better cushion and traction (Cook et al., 2004) and, being inorganic, it provides minimal nutritive support to mastitis pathogens. However, not all producers consider sand a feasible alternative for their operations. Inherent properties of sand can make it difficult to handle in some manure systems. Recent improvements in anaerobic digestion and solids separation technology as well as the associated environmental benefits make digesters an attractive option for dairy producers. Large amounts of bedding can be obtained from mechanical separation of manure as long as the equipment is well maintained and operates properly. It has been shown that the use of large amounts of bedding in stalls can optimize cow comfort, minimize lameness, reduce hock lesions, and increase cow longevity if udder health is not compromised (Tucker and Weary, 2004). Recent research by van Gastelen et al. (2011) indicated that the prevalence of hock lesions was higher on farms using foam mattresses than on farms using deep bedding (box compost, sand, or horse manure). 
However, among the 3 sources of deep bedding, horse manure had the highest bacterial counts.

Similarly to any other organic bedding material, recycled manure solids (RMS) provide bacteria with the nutrients necessary for growth. Several studies have investigated the ability of RMS to promote the growth of environmental bacteria compared with other common bedding sources and report that bacterial counts were greatest with RMS (Zehner et al., 1986; Godden et al., 2008). Such studies have suggested that certain chemical and physical properties of bedding materials may influence the growth of bacteria (Janzen et al., 1982; Godden et al., 2008). Previous research has shown a positive relationship between bacteria types and counts in bedding materials to those found on the teat ends of cows (Hogan and Smith, 1997; Zdanowicz et al., 2004), and clinical mastitis rates have been reported to be associated with bacterial counts in bedding (Hogan et al., 1989).

Because of the perception that RMS has high bacterial counts, some dairy producers and other professionals in the dairy industry are skeptical about using RMS successfully as bedding for dairy cows. Research data on the use and characteristics of RMS in the US Midwest were not available. Therefore, the objectives of this study were to (1) characterize RMS as a bedding material, (2) describe different methods for obtaining RMS, (3) document management practices, and (4) compare characteristics of RMS obtained from different systems. We expect that a study conducted in the Midwest can provide information applicable to other regions with a similar climate, husbandry system, and cattle genetics. In other parts of the study (A. Husfeldt, University of Minnesota; unpublished results), we documented lameness and hock lesion prevalence, cow hygiene, milk quality, mastitis incidence, and mortality rates, and investigated risk factors for high SCC in herds using RMS for bedding freestalls.

\section{MATERIALS AND METHODS}

\section{Farms}

This observational study was conducted on 38 Midwest dairy operations using RMS for bedding the freestalls of lactating dairy cows. Herds were visited once between July and October 2009 to collect bedding samples and observe methods of reclaiming manure solids for bedding. Herds included in this study were selected based on previous use of RMS as a primary bedding material for lactating dairy cows (either on top of mattresses or in deep beds) for a period of at least 1 yr before our visit. During the visit, producers were provided with a questionnaire designed to gather information related to the method of obtaining manure solids as well as bedding and other management practices. The questionnaire consisted of 50 questions related to herd characteristics, record system management, bedding frequency, stall maintenance, RMS use and characteristics, anaerobic digester type, dimensions, design, and use (when applicable), separator use and maintenance, presence of a mechanical blower, manure system management, and so on. Study herds were identified by extension educators, industry representatives, and other dairy producers. Following the identification of potential herds for use in this study, dairy producers were contacted to confirm the use of RMS for a period of at least $1 \mathrm{yr}$ and to obtain their consent to participate in the study.

\section{Bedding Analysis}

Composite samples of both the unused and used bedding material were obtained from each herd for bacterial and chemical analyses. Approximately $150 \mathrm{~g}$ of unused bedding material was collected at 10 different locations from the newly separated pile of RMS in a clean bucket, the entire sample was thoroughly mixed, and a 300-g composite sample was taken from the mixed material for later analysis. Approximately 80-g samples (approximately $2.4 \mathrm{~cm}$ deep) of used bedding material were obtained from the center of the surface of the back one-third of every fifth stall in each lactating pen and 1 dry cow pen. After thoroughly mixing the material, a 300-g composite sample was collected per pen. Stall samples were taken just before the addition of new bedding and in most cases on the day of bedding. Immediately after collection, samples were frozen and later transported in a cooler to the University of Minnesota where they were stored at $-40^{\circ} \mathrm{C}$ until analysis. Bedding depth was estimated before the addition of fresh bedding by visual observation of stalls with mattresses (which had RMS as bedding source on the surface of the stalls). In deep-bedded stalls, bedding depth was measured in the back one-third of the stall using a steel rod manually driven through the bedding material to the stall base and measuring the portion of the steel rod above the stall surface.

Bacteriological Analysis. Composite unused and stall bedding samples from each dairy were analyzed for bacterial populations by the University of Minnesota Laboratory for Udder Health. Overall, 38 unused RMS bedding samples (25 digested, 9 separated raw, and 4 drum-composted) and 308 used RMS bedding samples were analyzed (199 digested, 71 separated raw, and 38 drum-composted). Frozen bedding samples were allowed to thaw in a refrigerator before analysis. First, $50 \mathrm{~cm}^{3}$ of loose bedding material was measured using a sterile 
container and placed into a Whirl-Pak bag (Nasco, Fort Atkinson, WI). Then, $250 \mathrm{~cm}^{3}(\mathrm{~mL})$ of sterile distilled water was added to the bedding material, which was mixed and allowed to stand for $10 \mathrm{~min}$. The sample was mixed again, a liquid sample was removed by pipette, and serial 10-fold dilutions were made in sterile brain heart infusion broth (BD Biosciences, Franklin Lakes, NJ). Sample dilutions were plated $(200 \mu \mathrm{L})$ on colistin naladixic acid (CNA) agar (BBL, Sparks, MD), MacConkey agar (BBL), and TKT agar medium. Colony counts were determined for each sample after $24 \mathrm{~h}$ of incubation at $37^{\circ} \mathrm{C}$. Bacterial groups were identified as coliforms (lactose-positive colonies on MacConkey agar), Bacillus spp. (growth on CNA agar and grampositive), Streptococcus spp. (growth on TKT agar), and CNS (growth on the CNA agar and catalase activity). Bacterial counts were expressed as colony-forming units per milliliter of bedding sample.

Chemical Analysis. Composite unused and stall bedding samples from only the high-production, lowproduction, first-lactation, and dry cow groups (as defined by herd managers) were used for chemical analyses. The total number of used RMS bedding samples analyzed was 128 (85 digested, 29 separated raw, and 14 drum-composted). Representative subsamples were prepared to measure $\mathrm{pH}$ by adding $5 \mathrm{~g}$ of RMS bedding to $50 \mathrm{~mL}$ of sterile distilled water, mixing well, and allowing the bedding-water mixture to stand for 30 min with mixing every $10 \mathrm{~min}$. The $\mathrm{pH}$ was measured using a Thermo Orion Model $410 \mathrm{pH}$ meter (Thermo Fisher Scientific, Waltham, MA) calibrated to buffers $\mathrm{pH} 4$ and 7. Remaining bedding samples were dried in a $60^{\circ} \mathrm{C}$ forced-air oven for $48 \mathrm{~h}$ and then ground in a cyclone mill with a $1-\mathrm{mm}$ screen before chemical analysis. Samples were weighed before and after drying. To obtain absolute DM, subsamples were dried in an oven at $100^{\circ} \mathrm{C}$ for $24 \mathrm{~h}$. In both cases, samples were not allowed to cool before weighing. The NDF content was determined using the Ankom ${ }^{200}$ fiber system with sodium sulfite and $\alpha$-amylase (Ankom Technology Corp., Fairport, NY). Fat content was determined by petroleum ether extraction using the Ankom ${ }^{\text {XT100 }}{ }^{\text {sys- }}$ tem (Ankom Technology Corp.). Ash content, total N, total $\mathrm{C}, \mathrm{C}: \mathrm{N}$ ratio, and total $\mathrm{P}$ and $\mathrm{K}$ analysis was performed by the University of Minnesota Soil Testing and Analytical Laboratory (St. Paul). Ash content was determined by placing a 0.5 -g sample in a forced-air oven heated to $485^{\circ} \mathrm{C}$ for $10 \mathrm{~h}$. Samples were cooled in a vacuum desiccator and percentage ash was calculated. Total $\mathrm{N}$ and $\mathrm{C}$ were determined simultaneously using an Elementar Vario MAX CN combustion analyzer (Elementar Americas Inc., Mt. Laurel, NJ). Total P and K were determined by inductively coupled plasma atomic emission spectrometry [ARL (Fisons) model 3560 ICPAES, Thermo Fisher Scientific].

\section{Statistical Analysis}

The MEANS procedure (SAS Institute Inc., Cary, NC) was used to describe average farm measurements such as herd size, daily milk yield, bulk tank SCC, and overall bedding characteristics. The CORR procedure (SAS Institute Inc.) was used to investigate the correlations between characteristics of unused and used bedding. Associations between bedding characteristics and method of obtaining RMS (post-digestion, separated raw, or drum-composted) were evaluated using the MIXED procedure (SAS Institute Inc.). The method of obtaining RMS was used as the explanatory variable in all models. For the analysis of bedding moisture of unused bedding samples, the use of an additional drying method after separation (mechanical blower) was included as an additional explanatory variable in the model. For the analysis of used bedding samples, bedding frequency (how often fresh bedding was added to the stalls) per week was included as an additional explanatory variable in the model. The Tukey-Kramer adjustment was used to compare the least squares means for methods of obtaining RMS. Individual samples (fresh bedding $=$ composite farm samples; stalls $=$ composite pen samples) were used as the experimental unit for analysis of bedding characteristics. Farm was used as a random effect.

\section{RESULTS AND DISCUSSION}

\section{Farm Characteristics}

Thirty-eight Midwest dairy operations from Wisconsin (26), Minnesota (6), South Dakota (4), and Iowa (2) were included in this study. Anaerobic digestion preceded mechanical manure solids separation on $50 \%$ of the farms, with plug-flow digesters (14) being more common than complete-mix digesters (5). Farms without anaerobic digesters separated raw manure for bedding (13) or purchased RMS from dairies with anaerobic digesters (6). Of the 13 farms separating raw manure for bedding, 4 farms composted RMS in a mechanical drum for 18 to $24 \mathrm{~h}$ before use as bedding.

Nineteen farms were using RMS in deep-bedded freestalls, whereas 15 farms used RMS on top of mattresses, and 4 farms had both deep beds and mattresses. Stall lengths (mean $\pm \mathrm{SD}$ ) were $232.2 \pm 15.0$ and $217.9 \pm 15.7 \mathrm{~cm}$, stall widths were $119.6 \pm 4.8 \mathrm{~cm}$ and $118.4 \pm 4.6 \mathrm{~cm}$, body resting lengths were 178.1 \pm 6.4 and $175.0 \pm 5.3 \mathrm{~cm}$, and neckrail heights were 
$117.3 \pm 5.8$ and $117.6 \pm 6.1 \mathrm{~cm}$ for deep-bedded and mattress-based freestalls, respectively.

Thirty-two farms had naturally ventilated freestall barns, 1 farm had a cross-ventilated freestall barn, and 5 farms had tunnel-ventilated freestall barns. All naturally ventilated freestall barns had mixing fans over the feed alley. In addition, 28 of the naturally ventilated freestall barns had mixing fans over the freestalls directing air flow slightly downward toward the stalls. Distance between fans ranged from 6 to $22 \mathrm{~m}$. In the cross-ventilated barn, exhaust fans approximately 152 $\mathrm{cm}$ in diameter lined the north wall of the facility and pulled air across the width of the barn. Farms with tunnel-ventilated freestall barns had fans approximately $152 \mathrm{~cm}$ in diameter that lined either the south or east end of the barn depending on barn orientation. Fans were mounted side by side from the base of the barn to the peak of the roof and used to pull air across the length of the freestall barn.

Automated scrapers cleaned the alleys within pens on 13 farms, whereas 25 farms manually scraped alleys with skid loaders or tractors. Dry cows were housed in freestalls bedded with manure solids on $75 \%$ of farms and the remaining $25 \%$ of farms used alternative bedding sources in freestalls or housed cows in beddedpack barns.

Herd size averaged 1,300 cows and ranged from 130 to 3,700 cows. Holstein was the primary breed on $95 \%$ of the herds and Jersey was the primary breed in the remaining $5 \%$ of herds. Average daily milk production was $35.0 \mathrm{~kg} /$ cow and ranged from 18.2 to $45.5 \mathrm{~kg} /$ cow; yearly milk bulk tank SCC was $274,000( \pm 98,000)$ cells/mL. The SCC in the current study compared favorably to a recent study in Minnesota and South Dakota with sand-based freestalls, where the average SCC was 305,000 cells/mL (Lobeck et al., 2011). We consider this to be an indicator that RMS can be a viable bedding source for dairy cows from a milk quality perspective.

\section{Method of Obtaining Manure Solids}

Manure solid-liquid separation can be achieved using several techniques, including gravity settling, rundown screens, vibrating screens, centrifuges, and screw and roller presses (White, 1980). In the current study, all farms used mechanical screw press separators to obtain RMS, and 19 of the 38 farms used anaerobic digestion before mechanical separation of manure. Anaerobic digestion produces methane gas, which can be used to generate electricity; it also has been reported to reduce pathogens, farm odors, and greenhouse gas emissions (EPA, 2002; Wilkie, 2005). Although the process of anaerobic digestion is often used before mechanical separation of manure solids, it may not be feasible for all dairy operations because capital investments can be substantial and the potential profitability appears to be greater for larger dairy operations (Leuer et al., 2008). Average herd size of farms using anaerobic digesters was 1,755 cows, with a range of 130 to 3,673 cows. Removing the only small herd that had an experimental smaller scale digester (130 cows) from this data set increased the average herd size to 1,845 cows (range 700 to 3,673 cows).

On the 13 farms where anaerobic digesters were not used, producers mechanically separated raw manure and either used it without treatment or subjected the RMS to mechanical drum-composting for 18 to $24 \mathrm{~h}$ at approximately $65.5^{\circ} \mathrm{C}$. Nine herds used separated raw RMS and 4 herds used RMS after drum-composting. Average herd size was 1,025 (range 700 to 1,295 ) cows for farms utilizing a drum-composting unit and 1,105 (range 140 to 2,378) cows for farms separating raw manure solids.

Six herds in this study purchased digested RMS from another dairy operation. In these herds, RMS were stockpiled for a period of 1 to $3 \mathrm{wk}$ and used as needed by the dairy producer. In herds purchasing RMS, herd size was 542 (range 154 to 1,396 ) cows.

\section{RMS Chemical and Bacteriological Characteristics}

Unused RMS moisture was $72.4 \%( \pm 6.0)$ with a $\mathrm{pH}$ of $9.16( \pm 0.2)$. Samples contained $1.4 \%( \pm 0.2) \mathrm{N}$, $44.9 \%( \pm 1.1)$ C, $32.7( \pm 5.2)$ C:N ratio, $0.44 \%( \pm 0.19)$ $\mathrm{P}, 0.70 \%( \pm 0.21) \mathrm{K}, 76.5 \%( \pm 2.5) \mathrm{NDF}, 9.4 \%( \pm 2.0)$ ash, $4.4 \%( \pm 1.6)$ NFC, and $1.1 \%( \pm 0.5)$ fat. Total bacterial counts in unused bedding averaged 4,211,927 cfu/ $\mathrm{mL}$ (range 325 to $23,373,500 \mathrm{cfu} / \mathrm{mL}$ ). Proportionally, samples had $58.0 \%$ Bacillus spp., $37.2 \%$ environmental streptococci, $4.0 \%$ Staphylococcus spp., and $0.9 \%$ coliforms.

Used bedding samples had an average moisture content of $50.4 \%( \pm 12.6)$ and a pH of $9.39( \pm 0.2)$. They contained $71.3 \%( \pm 4.1) \mathrm{NDF}, 12.2 \%( \pm 4.2)$ ash, $1.9 \%$ $( \pm 0.4) \mathrm{N}, 43.0 \%( \pm 2.1) \mathrm{C}$, and had a C:N ratio of 22.6 $( \pm 4.3)$. Total bacterial population in used bedding was $13,285,010 \mathrm{cfu} / \mathrm{mL}$ (range 25,100 to $73,036,500$ $\mathrm{cfu} / \mathrm{mL}$ ). Proportionally, bedding samples had $51 \%$ Bacillus spp., 39.3\% environmental streptococci, $7.4 \%$ Staphylococcus spp., and 2.2\% coliforms.

Correlations between unused and used RMS bedding characteristics (Table 1) were greatest for ash, total C, total N, moisture, and counts of Staphylococcus spp. The RMS bedding characteristics least correlated included $\mathrm{pH}, \mathrm{NDF}$, and counts of environmental streptococci. 
Table 1. Bedding characteristic correlations between unused and used recycled manure solids in freestall dairy barns in the Midwest

\begin{tabular}{lrr}
\hline Characteristic & $\mathrm{r}$ & \multicolumn{1}{c}{$P$-value } \\
\hline Moisture (\%) & 0.48 & $<0.0001$ \\
NDF (\%) & -0.17 & 0.0158 \\
NFC (\%) & 0.28 & 0.0002 \\
Ash (\%) & 0.62 & $<0.0001$ \\
Total N (\%) & 0.53 & $<0.0001$ \\
Total C (\%) & 0.58 & $<0.0001$ \\
pH & 0.16 & 0.0309 \\
Bacillus spp. (cfu/mL) & 0.44 & $<0.0001$ \\
Coliforms (cfu/mL) & 0.22 & 0.0032 \\
Environmental streptococci (cfu/mL) & 0.16 & 0.0322 \\
Staphylococcus spp. (cfu/mL) & 0.52 & $<0.0001$ \\
Total bacteria (cfu/mL) & 0.31 & $<0.0001$ \\
\hline
\end{tabular}

\section{Bedding Comparisons}

Jørgensen and Jensen (2009) showed that variation existed in the chemical and biochemical properties of manure solids obtained from different types of separation systems. Previous research has suggested that differences in chemical and physical properties of bedding materials may influence the growth of bacteria (Janzen et al., 1982; Godden et al., 2008). Anaerobic digestion utilizes organic material to produce methane and has been reported to reduce the amount of pathogens present in material (effluent) leaving the system (Wright, 2001). Composting involves the decomposition of organic materials (NRAES, 1992) and has been shown to reduce bacterial counts in unused manure solids compared with noncomposted manure solids (Bishop et al., 1981). For this study, we compared the chemical and bacteriological characteristics of unused and used RMS obtained from anaerobic digestion, drum-composting, and separated raw manure intended for use as dairy bedding to investigate potential similarities and differences.

Unused RMS Bedding. Drum-composted manure solids contained 12 percentage units less moisture $(P<$ $0.0001)$ than both digested and separated raw manure solids (Table 2). Composted solids also had a higher $(P$ $<0.01) \mathrm{NDF}$ content $(80.0 \%)$ than digested $(75.6 \%)$ solids. Manure solids obtained post-digestion contained less $(P<0.01)$ NFC $(3.2 \%)$ than separated raw manure solids $(6.2 \%)$ and also contained a higher $(P<$ $0.01)$ percentage of ash $(10.2 \%)$ than either composted $(6.8 \%)$ and separated raw $(8.1 \%)$ solids. Greater ash content was also found in digested manure solids by Jørgensen and Jensen (2009). These authors suggested that volatile solids digestion leads to higher concentrations of ash. Total $\mathrm{N}$ content was greater in digested solids $(1.5 \%)$ than in composted $(1.3 \% ; P<0.05)$ and separated raw $(1.2 \% ; P<0.0001)$ solids. Because samples were dried before $\mathrm{N}$ analysis, ammonia could be lost and this could affect total $\mathrm{N}$ content. It is unknown whether ammonia concentration varies among RMS types. The C:N ratio was lower in digested solids (30.2) than in composted $(35.9 ; P<0.05)$ and separated raw $(38.9 ; P<0.0001)$ solids. These results are similar to those found by Jørgensen and Jensen (2009), in which digested manure solids contained a higher concentration of total $\mathrm{N}$ and lower $\mathrm{C}: \mathrm{N}$ ratio compared with separated raw manure solids. Phosphorous concentration was greater $(P<0.0001)$ in digested solids $(0.54 \%)$ than in composted $(0.24 \%)$ and separated raw $(0.23 \%)$ solids. These results are similar to those reported by Jørgensen and Jensen (2009). Although levels of potassium were numerically greater in digested solids, no significant difference was detected. Differences in $\mathrm{pH}$ were observed among digested (9.26), composted (9.09), and separated raw (8.93) solids.

Separated raw manure solids contained the greatest total counts of bacteria before use as freestall bedding. In particular, populations of Bacillus spp., coliforms, and environmental streptococci were greater than in digested and composted manure solids (Table 3). Populations of Bacillus spp. and environmental streptococci were similar between digested and composted solids. No difference was found in the populations of Staphylococcus spp. between digested, composted, and separated raw manure solids. Coliform bacteria were not detected in unused samples of composted solids, in agreement with the findings of Bishop et al. (1981).

Used RMS Bedding. Composted solids had lower $(P<0.001)$ moisture content $(41.3 \%)$ than digested $(55.9 \%)$ and separated raw $(57.2 \%)$ solids (Table 4). Digested solids had lower NDF content $(70.5 \%)$ than composted $(75.0 \% ; P<0.001)$ and separated raw $(73.1 \% ; P<0.05)$ solids. Total $\mathrm{N}$ content was greater $(P<0.01)$ in digested solids $(2.0 \%)$ than in separated raw $(1.7 \%)$ solids. Percentage total $\mathrm{C}$ was lower $(P<$ $0.01)$ in digested solids $(42.6 \%)$ than in composted solids $(44.7 \%)$ and the $\mathrm{C}: \mathrm{N}$ ratio was lower $(P<0.001)$ for digested solids (21.1) than for composted (25.6) and separated raw (25.0) solids. Separated raw manure solids tended $(P=0.07)$ to contain less total C $(43.2 \%)$ than composted solids. Ash content was greater in digested solids $(12.7 \%)$ than in composted $(7.4 \% ; P<$ $0.0001)$ and separated raw $(9.9 \% ; P<0.05)$ manure solids.

Bacterial counts among the different types of manure solids were more similar after use as freestall bedding; however, digested manure solids contained less total bacteria than composted $(P<0.001)$ and separated raw manure solids $(P=0.006)$. Coliform bacteria, not present in composted solids before use as bedding, were found in amounts similar to that of digested and separated raw manure solids after use as freestall bedding 
Table 2. Least squares means and standard errors for chemical composition of digested, composted, and separated raw manure solids before use as bedding in freestall barns in the Midwest

\begin{tabular}{|c|c|c|c|c|c|c|}
\hline \multirow[b]{3}{*}{ Characteristic } & \multicolumn{6}{|c|}{ Type of solids } \\
\hline & \multicolumn{2}{|c|}{ Digested } & \multicolumn{2}{|c|}{ Composted } & \multicolumn{2}{|c|}{ Raw } \\
\hline & LSM & $\mathrm{SE}$ & LSM & $\mathrm{SE}$ & LSM & $\mathrm{SE}$ \\
\hline Moisture (\%) & $72.9^{\mathrm{a}}$ & 0.7 & $60.3^{\mathrm{b}}$ & 1.6 & $72.6^{\mathrm{a}}$ & 1.1 \\
\hline $\mathrm{NDF}(\%)$ & $75.6^{\mathrm{a}}$ & 0.4 & $80.0^{\mathrm{b}}$ & 1.1 & $77.2^{\mathrm{ab}}$ & 0.7 \\
\hline NFC $(\%)$ & $3.8^{\mathrm{a}}$ & 0.3 & $4.4^{\mathrm{ab}}$ & 0.6 & $6.2^{\mathrm{b}}$ & 0.5 \\
\hline Fat $(\%)$ & 1.1 & 0.1 & 0.8 & 0.3 & 1.3 & 0.2 \\
\hline Ash (\%) & $10.2^{\mathrm{a}}$ & 0.3 & $6.8^{\mathrm{b}}$ & 0.8 & $8.1^{\mathrm{b}}$ & 0.6 \\
\hline Total N (\%) & $1.5^{\mathrm{a}}$ & 0.03 & $1.3^{\mathrm{b}}$ & 0.09 & $1.2^{\mathrm{b}}$ & 0.05 \\
\hline Total C (\%) & 44.8 & 0.5 & 45.9 & 0.2 & 44.9 & 0.4 \\
\hline $\mathrm{C}: \mathrm{N}$ ratio & $30.3^{\mathrm{a}}$ & 0.8 & $35.9^{\mathrm{b}}$ & 1.9 & $38.9^{\mathrm{b}}$ & 1.3 \\
\hline Total P (\%) & $0.54^{\mathrm{a}}$ & 0.02 & $0.24^{\mathrm{b}}$ & 0.06 & $0.23^{\mathrm{b}}$ & 0.04 \\
\hline Total K (\%) & 0.74 & 0.04 & 0.63 & 0.10 & 0.64 & 0.07 \\
\hline $\mathrm{pH}$ & $9.26^{\mathrm{a}}$ & 0.02 & $9.09^{\mathrm{b}}$ & 0.05 & $8.93^{\mathrm{c}}$ & 0.04 \\
\hline
\end{tabular}

${ }^{\mathrm{a}-\mathrm{c}}$ Means within rows with different superscripts differ significantly $(P<0.05)$.

(Table 5). Environmental streptococci were present in lower concentrations $(P<0.001)$ in digested manure solids (14.14 ln $\mathrm{cfu} / \mathrm{mL})$ than in composted (15.54 ln $\mathrm{cfu} / \mathrm{mL})$ or separated raw (15.19 $\mathrm{ln} \mathrm{cfu} / \mathrm{mL})$ manure solids. Digested solids also contained fewer $(P<0.05)$ Bacillus spp. than separated raw manure solids. No differences were observed in counts of Staphylococcus spp.

\section{Digester Comparison}

Anaerobic digestion was being utilized by 19 of the 38 farms in this study, and 6 herds were purchasing digested solids from another dairy. Plug-flow digesters were most common, with 14 of the 19 herds using this type of digester. The remaining 5 herds used completemix digesters. Differences between systems include percentage solids of manure entering the digester, mixing of manure within the system, and most notably the design (Krich et al., 2005; Wilkie, 2005; Balsam and Ryan, 2006). Plug-flow digesters are usually built below grade and plugs of fresh manure enter the digester at one end and push out digested manure at the opposite end.
This type of system is capable of handling manure with 11 to $14 \%$ total solids (Balsam, 2002; Wilkie, 2005). Complete-mix digesters are typically silo-like tanks built above ground that use agitators to periodically mix digester contents. Complete-mix digesters handle manure with 3 to $10 \%$ total solids content (Balsam, 2002; Wilkie, 2005).

Only minor differences existed between unused RMS obtained from plug-flow compared with complete-mix digesters. The RMS from plug-flow digesters contained less $\mathrm{N}(1.4 \%)$ than that from complete-mix digesters $(1.6 \% ; P<0.01)$. This difference resulted in a greater C:N ratio $(P=0.03)$ for solids obtained from plug-flow (31.3) compared with complete-mix (27.7) digesters. Unused RMS bedding moisture, NDF, NFC, ash, total $\mathrm{C}$, $\mathrm{P}$, and $\mathrm{K}$ content, as well as $\mathrm{pH}$, were not different between digester types. Bacterial populations of $\mathrm{Ba}$ cillus spp., coliforms, environmental streptococci, and Streptococcus spp. were similar between unused RMS obtained from plug-flow and complete-mix digesters.

Used RMS from complete-mix digesters contained less moisture (49.0\%) than RMS from plug-flow digest-

Table 3. Least squares means of bacterial counts $(\mathrm{ln} \mathrm{cfu} / \mathrm{mL})$ in digested, composted, and separated raw manure solids before use as bedding in freestall barns in the Midwest

\begin{tabular}{|c|c|c|c|c|c|c|}
\hline \multirow[b]{3}{*}{ Population } & \multicolumn{6}{|c|}{ Type of solids } \\
\hline & \multicolumn{2}{|c|}{ Digested } & \multicolumn{2}{|c|}{ Composted } & \multicolumn{2}{|c|}{ Raw } \\
\hline & LSM & SE & LSM & $\mathrm{SE}$ & LSM & $\mathrm{SE}$ \\
\hline Bacillus spp. & $10.62^{\mathrm{a}}$ & 0.65 & $8.99^{\mathrm{a}}$ & 1.60 & $14.96^{\mathrm{b}}$ & 1.06 \\
\hline Coliforms & $4.02^{\mathrm{a}}$ & 0.42 & $0.00^{\mathrm{b}}$ & 1.04 & $9.37^{\mathrm{c}}$ & 0.69 \\
\hline Environmental streptococci & $9.42^{\mathrm{a}}$ & 0.75 & $9.21^{\mathrm{a}}$ & 1.83 & $14.81^{\mathrm{b}}$ & 1.22 \\
\hline Staphylococcus spp. & 3.37 & 0.97 & 2.36 & 2.37 & 7.01 & 1.58 \\
\hline Total & $12.00^{\mathrm{a}}$ & 0.46 & $11.96^{\mathrm{a}}$ & 1.13 & $15.70^{\mathrm{b}}$ & 0.75 \\
\hline
\end{tabular}

${ }^{\mathrm{a}-\mathrm{C}}$ Means within rows with different superscripts differ significantly $(P<0.05)$. 
Table 4. Least squares means of bedding characteristics for digested, composted, and separated raw manure solids after use as bedding in freestall barns in the Midwest

\begin{tabular}{|c|c|c|c|c|c|c|}
\hline \multirow[b]{3}{*}{ Characteristic } & \multicolumn{6}{|c|}{ Type of solids } \\
\hline & \multicolumn{2}{|c|}{ Digested } & \multicolumn{2}{|c|}{ Composted } & \multicolumn{2}{|c|}{ Raw } \\
\hline & LSM & $\mathrm{SE}$ & LSM & $\mathrm{SE}$ & LSM & $\mathrm{SE}$ \\
\hline Moisture (\%) & $55.9^{\mathrm{a}}$ & 1.9 & $41.3^{\mathrm{b}}$ & 3.6 & $57.2^{\mathrm{a}}$ & 3.1 \\
\hline $\operatorname{NDF}(\%)$ & $70.5^{\mathrm{a}}$ & 0.6 & $75.0^{\mathrm{b}}$ & 1.1 & $73.1^{\mathrm{b}}$ & 0.9 \\
\hline Ash $(\%)$ & $12.7^{\mathrm{a}}$ & 0.6 & $7.4^{\mathrm{b}}$ & 1.2 & $9.9^{\mathrm{b}}$ & 1.0 \\
\hline Total N (\%) & $2.0^{\mathrm{a}}$ & 0.04 & $1.8^{\mathrm{ab}}$ & 0.09 & $1.7^{\mathrm{b}}$ & 0.06 \\
\hline Total C (\%) & $42.6^{\mathrm{a}}$ & 0.2 & $44.7^{\mathrm{b}}$ & 0.5 & $43.2^{\mathrm{a}}$ & 0.4 \\
\hline $\mathrm{C}: \mathrm{N}$ ratio & $21.3^{\mathrm{a}}$ & 0.6 & $25.8^{\mathrm{b}}$ & 1.1 & $25.4^{\mathrm{b}}$ & 0.9 \\
\hline $\mathrm{pH}$ & 9.44 & 0.04 & 9.24 & 0.10 & 9.33 & 0.07 \\
\hline
\end{tabular}

ers $(57.5 \% ; P=0.01)$. Percentage NDF was greater in used RMS from complete-mix digesters (72.3\%) than RMS from plug-flow digesters $(70.5 \%, P=0.02)$. We observed a tendency $(P=0.07)$ for used RMS from plug-flow digesters to contain a greater percentage of ash $(13.9 \%)$ compared with that from complete-mix digesters $(12.0 \%)$. Although bacterial populations in used RMS were similar between digesters, populations of coliforms $(P=0.07)$ and Staphylococcus spp. $(P=0.09)$ tended to be greater in RMS from plug-flow digesters. These results may be due to unbalanced sample size because 18 herds were utilizing RMS from plug-flow anaerobic digesters and 7 herds were using RMS from complete-mix anaerobic digesters.

\section{Management Practices}

Nineteen herds in this study used RMS in deep-bedded freestalls, 15 herds used RMS on top of mattresses, and 4 herds used a combination of deep beds and mattress-based freestalls. Prior to the addition of new bedding, bedding depth across herds with deep-bedded freestalls was $22.1 \mathrm{~cm}$ and ranged between 7.6 and $30.5 \mathrm{~cm}$. In herds bedding RMS on top of mattresses, bedding depth averaged $9.1 \mathrm{~cm}$ and ranged from 5.1 to $15.2 \mathrm{~cm}$. Sixty percent of farms added fresh RMS bedding to the freestalls 3 or more times per week, whereas the remaining $40 \%$ added RMS bedding once (3) or twice a week. Farms using deep-bedded freestalls leveled the stall surface every other day, whereas farms with mattresses found it difficult to retain bedding in the stalls. Used bedding from mattress-based stalls had moisture content of $51.5 \pm 2.6 \%$, whereas used bedding from deep-bedded stalls had a moisture content of 55.8 $\pm 2.0 \%$. Bedding moistures were not different between stall types. Deep-bedded stalls had a tendency $(P=$ $0.08)$ to contain greater counts of coliform bacteria than mattress based stalls. Populations of environmental streptococci were greatest $(P<0.001)$ in RMS from stalls with mattresses (Table 6). Counts of Bacillus spp. and Staphylococcus spp. did not differ between stall types.

We observed producers using additional efforts to reduce the RMS moisture content. Reducing bedding moisture content is believed to impede bacterial growth (Bey et al., 2002). Ten farms used a mechanical blower to further reduce the moisture content of the freshly separated RMS. In all cases, freshly separated RMS were funneled into the mechanical blower and blown into the storage compartment within a shelter. Com-

Table 5. Least squares means of bacterial counts (ln cfu/mL) in digested, composted, and separated raw manure solids after use as bedding in freestall barns in the Midwest

\begin{tabular}{|c|c|c|c|c|c|c|}
\hline \multirow[b]{3}{*}{ Population } & \multicolumn{6}{|c|}{ Type of solids } \\
\hline & \multicolumn{2}{|c|}{ Digested } & \multicolumn{2}{|c|}{ Composted } & \multicolumn{2}{|c|}{ Raw } \\
\hline & LSM & SE & LSM & SE & LSM & SE \\
\hline Bacillus spp. & $14.13^{\mathrm{a}}$ & 0.17 & $14.66^{\mathrm{ab}}$ & 0.34 & $14.86^{\mathrm{b}}$ & 0.31 \\
\hline Coliforms & 10.77 & 0.16 & 10.62 & 0.32 & 11.21 & 0.29 \\
\hline Environmental streptococci & $14.14^{\mathrm{a}}$ & 0.11 & $15.54^{\mathrm{b}}$ & 0.24 & $15.19^{\mathrm{b}}$ & 0.18 \\
\hline Staphylococcus spp. & 12.06 & 0.27 & 13.23 & 0.65 & 11.71 & 0.52 \\
\hline Total & $15.55^{\mathrm{a}}$ & 0.33 & $17.01^{\mathrm{b}}$ & 0.49 & $16.50^{\mathrm{b}}$ & 0.33 \\
\hline
\end{tabular}

${ }^{\mathrm{a}, \mathrm{b}}$ Means within rows with different superscripts differ significantly $(P<0.05)$. 
Table 6. Least squares means of bacterial counts $(\mathrm{ln} \mathrm{cfu} / \mathrm{mL})$ in deep-bedded and mattress-based freestalls with recycled manure solids in the Midwest

\begin{tabular}{llllll}
\hline & \multicolumn{4}{c}{ Stall type } \\
\cline { 2 - 3 } & \multicolumn{2}{c}{ Deep beds } & & \multicolumn{2}{c}{ Mattress } \\
\cline { 2 - 3 } \cline { 5 - 6 } Population & LSM & SE & & LSM & SE \\
\hline Bacillus spp. & 14.37 & 0.18 & & 14.04 & 0.24 \\
Coliforms & 10.92 & 0.16 & & 10.51 & 0.23 \\
Environmental streptococci & $13.80^{\mathrm{a}}$ & 0.11 & & $15.45^{\mathrm{b}}$ & 0.13 \\
Staphylococcus spp. & 12.13 & 0.28 & & 12.00 & 0.40 \\
\hline
\end{tabular}

${ }^{\mathrm{a}, \mathrm{b}}$ Means within rows with different superscripts differ significantly $(P<0.05)$.

parison of RMS moisture content among farms that utilized a blower and farms that did not indicated that blown RMS were drier $(P=0.01)$. Blown RMS had a moisture content of $69.8 \%$ compared with $73.5 \%$ for RMS that was not blown. Twenty-nine farms had a shelter in which to store the manure solids before use. Sheltered manure solids were drier than nonsheltered manure solids $(P=0.04)$. Average moisture of sheltered manure solids was $71.7 \%$ compared with $74.9 \%$ for nonsheltered manure solids. These additional efforts to reduce the moisture content of RMS did not appear to reduce bacterial growth in the current study. This result may be due to the relatively minor reduction in moisture levels observed when manure solids were blown or sheltered.

\section{CONCLUSIONS}

This was the first survey of herds using RMS for bedding in the US Midwest. We learned that RMS was being used successfully as a source of bedding for dairy cows. The use of RMS offers major advantages in cost and availability compared with traditional organic sources of bedding. The SCC for most herds in this study was comparable to the average SCC in the region, and not excessively high, as is sometimes perceived by producers not utilizing RMS as bedding. Differences in the chemical and bacteriological characteristics of digested, drum-composted, and separated raw RMS were found before use as bedding. These differences were likely due to the processes of anaerobic digestion and drum-composting. Bacteriological differences existed in unused RMS but were minor after use as freestall bedding. For example, stall coliform counts were similar for all 3 types of RMS. Minor differences existed between RMS obtained from plug-flow and completemix digesters. Bedding RMS on top of mattresses was associated with lower bedding moisture and greater concentrations of environmental streptococci. Utilizing mechanical blowers and storing RMS in a shelter were associated with lower RMS bedding moisture but not associated with bacterial counts.

\section{ACKNOWLEDGMENTS}

We thank the dairy producers who participated in this study and the extension educators and industry representatives who helped us identify cooperating farms. This project was funded by the University of Minnesota Rapid Agricultural Response Fund.

\section{REFERENCES}

Balsam, J., and D. Ryan. 2006. Anaerobic digestion of animal wastes: Factors to consider. Accessed June 3, 2010. https://attra.ncat.org/ attra-pub/summaries/summary.php?pub=307.

Bey, R. F., J. K. Reneau, and R. J. Farnsworth. 2002. The role of bedding management in udder health. Pages 45-55 in National Mastitis Council Annual Meeting Proceedings. National Mastitis Council, Arlington, VA.

Bishop, J. R., J. J. Janzen, A. B. Bodine, C. A. Caldwell, and D. W. Johnson. 1981. Dairy waste solids as a possible source of bedding. J. Dairy Sci. 64:706-711.

Cook, N. B., T. B. Bennett, and K. V. Nordlund. 2004. Effect of freestall surface on daily activity patterns in dairy cows with relevance to lameness prevalence. J. Dairy Sci. 87:2912-2922.

EPA. 2002. Managing manure with biogas recovery systems: Improved performance at competitive costs. Accessed June 3, 2010. http:// tammi.tamu.edu/biogas2.pdf.

Godden, S., R. Bey, K. Lorch, R. Farnsworth, and P. Rapnicki. 2008. Ability of organic and inorganic bedding materials to promote growth of environmental bacteria. J. Dairy Sci. 91:151-159.

Hogan, J. S., and K. L. Smith. 1997. Bacteria counts in sawdust bedding. J. Dairy Sci. 80:1600-1605.

Hogan, J. S., K. L. Smith, K. H. Hoblet, D. A. Todhunter, P. S. Schoenberger, W. D. Hueston, D. E. Pritchard, G. L. Bowman, L. E. Heider, B. L. Brockett, and H. R. Conrad. 1989. Bacterial counts in bedding materials used on nine commercial dairies. J. Dairy Sci. $72: 250-258$.

Janzen, J. J., J. R. Bishop, A. B. Bodine, C. A. Caldwell, and D. W. Johnson. 1982. Composted dairy waste solids and crushed limestone as bedding in free stalls. J. Dairy Sci. 65:1025-1028.

Jørgensen, K., and L. A. Jensen. 2009. Chemical and biochemical variation in animal manure solids separated using different commercial separation technologies. Bioresour. Technol. 100:3088-3096.

Krich, K., D. Augenstein, J. P. Batmale, J. Benemann, B. Rutledge, and D. Salour. 2005. Biomethane from dairy waste: A sourcebook for the production and use of renewable natural gas in California. Accessed June 4, 2010. http://www.suscon.org/cowpower/ biomethaneSourcebook/biomethanesourcebook.php.

Leuer, E. R., J. Hyde, and T. L. Richard. 2008. Investing in methane digesters on Pennsylvania dairy farms: Implications on scale economics and environmental programs. Agric. Resour. Econ. Rev. $37: 188-203$.

Lobeck, K. M., M. I. Endres, E. M. Shane, S. M. Godden, and J. Fetrow. 2011. Animal welfare in cross-ventilated, compost bedded 
pack, and naturally ventilated dairy barns in the upper Midwest. J. Dairy Sci. 94:5469-5479.

NRAES. 1992. On-Farm Composting Handbook. R. Rynk, ed. NRAES-54. Northeast Regional Agricultural Engineering Service, Ithaca, NY.

Tucker, C. B., and D. M. Weary. 2004. Bedding on geotextile mattresses: How much is needed to improve cow comfort? J. Dairy Sci. 87:2889-2895.

van Gastelen, S., B. Westerlaan, D. J. Houwers, and F. J. C. M. van Eerdenburg. 2011. A study on cow comfort and risk for lameness and mastitis in relation to different types of bedding materials. J. Dairy Sci. 94:4878-4888.

White, R. K. 1980. The role of liquid-solid separation in today's livestock waste management systems. J. Anim. Sci. 50:356-359.

Wilkie, A. C. 2005. Anaerobic digestion of dairy manure: Design and process considerations. Pages 301-312 in Dairy Manure
Management: Treatment, Handling, and Community Relations. NRAES-176. Natural Resource, Agriculture, and Engineering Service, Cornell University, Ithaca, NY.

Wright, P. 2001. Overview of anaerobic digestion systems for dairy farms. Pages 1-15 in Dairy Manure Systems: Equipment and Technology. NRAES-143. Natural Resource, Agriculture, and Engineering Service, Cornell University, Ithaca, NY.

Zdanowicz, M., J. A. Shelford, C. B. Tucker, D. M. Weary, and M. A. G. Von Keyerlingk. 2004. Bacterial populations on teat ends of dairy cows housed in free stalls and bedded with either sand or sawdust. J. Dairy Sci. 87:1694-1701.

Zehner, M. M., R. J. Farnsworth, R. D. Appleman, K. Larntz, and J. A. Springer. 1986. Growth of environmental mastitis pathogens in various bedding materials. J. Dairy Sci. 69:1932-1941. 